\title{
INHIBITORY EFFECT OF ENTEROCIN WITH SOME FOOD ADDITIVES ON ESCHERICHIA COLI O18 IN UHT MILK
}

\author{
RANIA M. EWIDA and ENAS EL-PRINCE \\ ${ }^{1}$ Department of Food Hygiene (Milk Hygiene), Faculty of Veterinary Medicine, New Valley University \\ ${ }^{2}$ Department of Food Hygiene (Milk Hygiene), Faculty of Veterinary Medicine, Assiut University, Egypt
}

Received: 30 September 2018; Accepted: 30 October 2018

\begin{abstract}
Biopreservation is the oldest method for food preservation by addition of natural compounds to the food to increase its shelf-life and inhibit the growth of foodborne pathogens. Enterocin is a protein produced by Enterococcus faecium which have a great effect on Gram-positive bacteria, but it has limited effect on Gramnegative bacteria. The aim of this work is to study the addition of food additives as honey and EDTA to increase the inhibitory effect of enterocin against Escherichia coli O18 in UHT milk stored at ambient and refrigerator temperatures. The UHT milk inoculated with $E$. coli $\mathrm{O} 18$ was divided into 8 parts as the following, the first part without any additives as control, the second with $10 \%$ honey, the third and fourth parts contained $10 \%$ honey with different concentrations of enterocin $(150$ and $300 \mu \mathrm{g} / \mathrm{ml})$, respectively. Each part of these prepared four parts was divided into two groups; the first group was stored at ambient temperature $\left(30 \pm 2{ }^{\circ} \mathrm{C}\right)$ while, the second group was stored at refrigerator temperature $\left(4 \pm 2{ }^{\circ} \mathrm{C}\right)$ for 24 hours. The obtained results showed that, the most effective treatment was the $10 \%$ honey and enterocin $(300 \mu \mathrm{g} / \mathrm{ml})$ and stored in the refrigerator where the count of E. coli $\mathrm{O} 18$ reduced from $6 \times 10^{6} \mathrm{cfu} / \mathrm{ml}$ to $7.1 \times 10^{4} \mathrm{cfu} / \mathrm{ml}$ at the end of $24 \mathrm{~h}$. Also, another trail was done as the previous experiment except the replacement of the honey with EDTA $(20 \mathrm{mM})$. The highest inhibitory effect of the treatments obtained by the addition of EDTA $(20 \mathrm{mM})$ with enterocin $(300 \mu \mathrm{g} / \mathrm{ml})$ which was stored at the refrigerator temperature. The count of $E$. coli $\mathrm{O} 18$ was reduced from $1.5 \times 10^{5} \mathrm{cfu} / \mathrm{ml}$ to $3.6 \times 10^{4} \mathrm{cfu} / \mathrm{ml}$ by the end of $24 \mathrm{~h}$. In conclusion, the addition of honey or EDTA with enterocin and preservation of milk in refrigerator temperature reduced $E$. coli $\mathrm{O} 18$ count. In addition, this method can be used as a safe method for preservation of milk which consumed directly or used in manufacture the milk products.
\end{abstract}

Key words: Enterocin, honey, EDTA, E. coli O18, UHT milk.

\section{INTRODUCTION}

In the recent years, food safety has become an important issue in many countries. Inhibition of food poisoning and spoilage bacteria by using natural compounds is of a great interest to the food industry due to its public health and economic concerns. Biopreservation can be defined as addition of natural compounds which have antibacterial effect to the food to increase its shelf life and inhibit the growth of foodborne pathogenic bacteria (Stiles, 1996).

Bacteriocins are ribosomal synthesized antimicrobial peptides produced by bacteria including lactic acid bacteria (LAB). LAB are Gram-positive bacteria as Lactobacillus spp., Lactococcus spp., Streptococcus spp. and

Corresponding author: RANIA M. EWIDA

E-mail address: r_ewida@aun.edu.eg

Present address: Department of Food Hygiene (Milk Hygiene), Faculty of Veterinary Medicine, New Valley University
Enterococcus spp. Enterococcus spp. include E. faecium and E. faecalis, which are natural inhabitant in the gastrointestinal tracts of humans and animals. These bacteria have great beneficial health effects in the host, which include the inhibition of the tumor cell lines (Ohasi et al., 1992; Park et al., 1999), treatment of diarrhea and reduction of hypercholesterolaemia (Reuter, 1997; Agerholm-Larsen et al., 2000).

Moreover, E. faecium produces bacteriocins, that inhibit foodborne bacteria and intestinal pathogens, and are used as biopreservatives in fermented dairy products. The class II enterococcal bacteriocins which include enterocins A, B, P and L 50 share the characteristics of low molecular weight, heat stability and non-lanthionin-containg peptide structure (Kang and Lee, 2005).

Enterocin causes antimicrobial activity by forming specific potassium ion-conducting pores in the cytoplasmic membranes of target cells, which causes a rapid and drastic efflux of the 
interacellulary accumulated potassium ions thus impairing the electrochemical transmembrane potential (Herranz and Driessen, 2005). However, generally most LAB bacteriocin are not active against the Gram-negative bacteria as the outer membrane of $E$. coliact as an impermeable barrier (Ruhr and Sahl, 1985; Kordel et al., 1989; van Belkum et al., 1991; García Garcera' et al., 1993), so it prevents molecules as antibiotics and detergents from reaching cytoplasmic membrane (Nikaido and Vaara, 1987). Therefore, the combination of bacteriocin with natural compounds, chemical and physical treatments lead to damage of the bacterial outer membrane and reduce of the foodborne pathogenic and spoilage bacteria significantly (Stevens et al., 1991; Kalchayanand et al., 1994; Schved et al., 1994; Cutter and Siragusa, 1995a and 1995b, Boziaris et al., 1998, Ananou et al., 2005; Osmanağaoğlu, 2005).

According to the aforementioned, the present study is directed to determine the efficacy of enteroicin on $E$. coli $\mathrm{O} 18$ in combination with natural compound as honey and chemical treatment as EDTA in the UHT milk stored in ambient and refrigerator temperatures during $24 \mathrm{~h}$.

\section{MATERIALS AND METHODS}

\section{Organisms identification:}

E. faecium strain was isolated from cheddar cheese and identified by microbiological and molecular identification in Molecular Biology Research Unit, Assiut University, Egypt. The molecular identification based on $16 \mathrm{~S}$ rRNA gene sequencing using 27F (5' AGAGTTTGATCCTGGCTCAG 3') and 1392R (5' GGTTACCTTGTTACGACTT 3') primer pairs (Applied Biosystem, USA) (Srinivasan et al., 2015). E. coliO18 strain was isolated from ice cream sample from a previous study by Ewida and Hussein (2018). Comparison of the 16S rRNA gene sequences with entries in the updated GenBank database (www.ncbi.nlm.nih.gov/ pubmed) was conducted using the Blast program. In addition, the two isolated strains were submitted (in 2018) in the Genebank after complete identification.

\section{Materials used:}

UHT milk was purchased from the dairy shops in Assiut city, Egypt. Citrus flower honey was purchased from the Faculty of Agriculture, Assuit University, Egypt, while, the EDTA was used in the experimental obtained from WINLAB, UK, Cat. No. E 10203.

\section{Culture conditions:}

E. faecium was propagated in De Mann Rogosa and Sharp (MRS) broth (TM Media, India) at $37^{\circ} \mathrm{C}$ for $24 \mathrm{~h}$ and $E$. coli $\mathrm{O} 18$ was grown in
Enterobacteriaceae Enrichment Broth (EE broth) (Himedia, India) at $37^{\circ} \mathrm{C}$ for $24 \mathrm{~h}$.

\section{Enterocin preparation:}

After E. faecium propagation in MRS broth, the culture was centrifuged at $10000 \mathrm{rpm}$ for $20 \mathrm{~min}$ under cooling $\left(4^{\circ} \mathrm{C}\right)$ using cooling centrifuge (Jouan, UK) to remove cells. The cells free supernatant (CFS) was passed through membrane filters with pore diameter of $0.22 \mu \mathrm{m}$ and then stored at $4^{\circ} \mathrm{C}$ till use as pure enterocin (Djadouni, 2017).

\section{Bacteriocin activity assay:}

A well diffusion assay procedure was used for determination of enterocin activity (Schillinger and Lucke, 1989). $100 \mu \mathrm{l}$ of the pure enterocin was placed in $5 \mathrm{~mm}$-in-diameter well of the plates seeded with Staphylococcus aureus strain (Animal Health Research Institute, Assiut, Egypt) as bioassay strain and E. coli O18as tested strain (precooled at $40^{\circ} \mathrm{C}$ of molten nutrient agar medium was inoculated with overnight culture obtained from single colony). After $24 \mathrm{~h}$ of incubation at $37{ }^{\circ} \mathrm{C}$, the clear zones of inhibition appeared and recorded.

\section{Effect of enterocin in combination with EDTA and honey on $E$. coli 018 in UHT milk:}

E. coli $\mathrm{O} 18$ suspensions of $\left(8.9 \times 10^{9} \quad \mathrm{CFU} / \mathrm{ml}\right)$ inoculated into UHT milk were exposed to the following treatments:(1) honey (10\%), (2) honey (10\%) with enterocin $(150 \mu \mathrm{g} / \mathrm{ml})$, (3) honey (10\%) with enterocin $(300 \mu \mathrm{g} / \mathrm{ml})$, (4) EDTA $(20 \mathrm{mM})$, (5) EDTA $(20 \mathrm{mM})$ with enterocin $(150 \mu \mathrm{g} / \mathrm{ml})$, (6) EDTA with enterocin $(300 \mu \mathrm{g} / \mathrm{ml})$ and the last part of milk was inoculated with $E$. coli without any treatments. During the incubation at ambient and refrigerator temp for $24 \mathrm{~h}$, samples were periodically taken and viable cell counts were determined using violet red bile agar (VRBA) plates at $37^{\circ} \mathrm{C}$ for $24 \mathrm{~h}$.

\section{Measurement of $\mathrm{pH}$ value:}

The $\mathrm{pH}$ value of each sample was determined according to the standard methods of A.P.H.A. (2004) with pH meter (Hanna, Portugal) previously standardized with buffer solution of $\mathrm{pH} 4.0$ and 7.0.

\section{RESULTS}

The strain of E. faecium was submitted in the Genbank and had accession number MH748622, while, the E. coli strain had accession number MH748624.

The enterocin activity was tested against Staph. aureus and the diameter of the inhibitory zone was $20 \mathrm{~mm}$. On the other side, the entrocin didn't give any inhibitory effect on $E$. coli $\mathrm{O} 18$. 
Table 1: The count and reduction $\%$ of $E$. coli $\mathrm{O} 18$ inoculated in UHT milk with $10 \%$ honey and enterocin at ambient temperature $\left(30 \pm 2{ }^{\circ} \mathrm{C}\right)$.

\begin{tabular}{|c|c|c|c|c|c|c|c|}
\hline \multirow[t]{2}{*}{ Period } & \multirow{2}{*}{$\begin{array}{l}\text { UHT milk Control } \\
\text { (additive free) }\end{array}$} & \multicolumn{2}{|c|}{$\begin{array}{l}\text { UHT milk with honey } \\
10 \%\end{array}$} & \multicolumn{2}{|c|}{$\begin{array}{l}\text { UHT milk with } \\
\text { honey \& enterocin } \\
(150 \mu \mathrm{g} / \mathrm{ml})\end{array}$} & \multicolumn{2}{|c|}{$\begin{array}{l}\text { UHT milk with } \\
\text { honey \& enterocin } \\
(300 \mu \mathrm{g} / \mathrm{ml})\end{array}$} \\
\hline & & $\begin{array}{l}\text { Count } \\
\mathrm{cfu} / \mathrm{ml}\end{array}$ & $\begin{array}{l}\text { Red. } \\
\%\end{array}$ & $\begin{array}{l}\text { Count } \\
\mathrm{cfu} / \mathrm{ml}\end{array}$ & $\begin{array}{l}\text { Red. } \\
\%\end{array}$ & $\begin{array}{l}\text { Count } \\
\mathrm{cfu} / \mathrm{ml}\end{array}$ & $\begin{array}{l}\text { Red. } \\
\%\end{array}$ \\
\hline $0 \mathrm{~h}$ & $6.0 \times 10^{6}$ & $6.0 \times 10^{6}$ & - & $6.0 \times 10^{6}$ & - & $6.0 \times 10^{6}$ & - \\
\hline $6 \mathrm{~h}$ & $2.0 \times 10^{8}$ & $9.0 \times 10^{6}$ & 95.50 & $5.0 \times 10^{6}$ & 97.50 & $1.0 \times 10^{6}$ & 99.50 \\
\hline $12 \mathrm{~h}$ & $9.4 \times 10^{10}$ & $2.9 \times 10^{10}$ & 69.15 & $1.1 \times 10^{8}$ & 99.88 & $3.0 \times 10^{6}$ & 99.99 \\
\hline $24 \mathrm{~h}$ & $1.9 \times 10^{12}$ & $3.7 \times 10^{10}$ & 98.05 & $2.5 \times 10^{10}$ & 98.68 & $5.0 \times 10^{7}$ & 99.99 \\
\hline
\end{tabular}

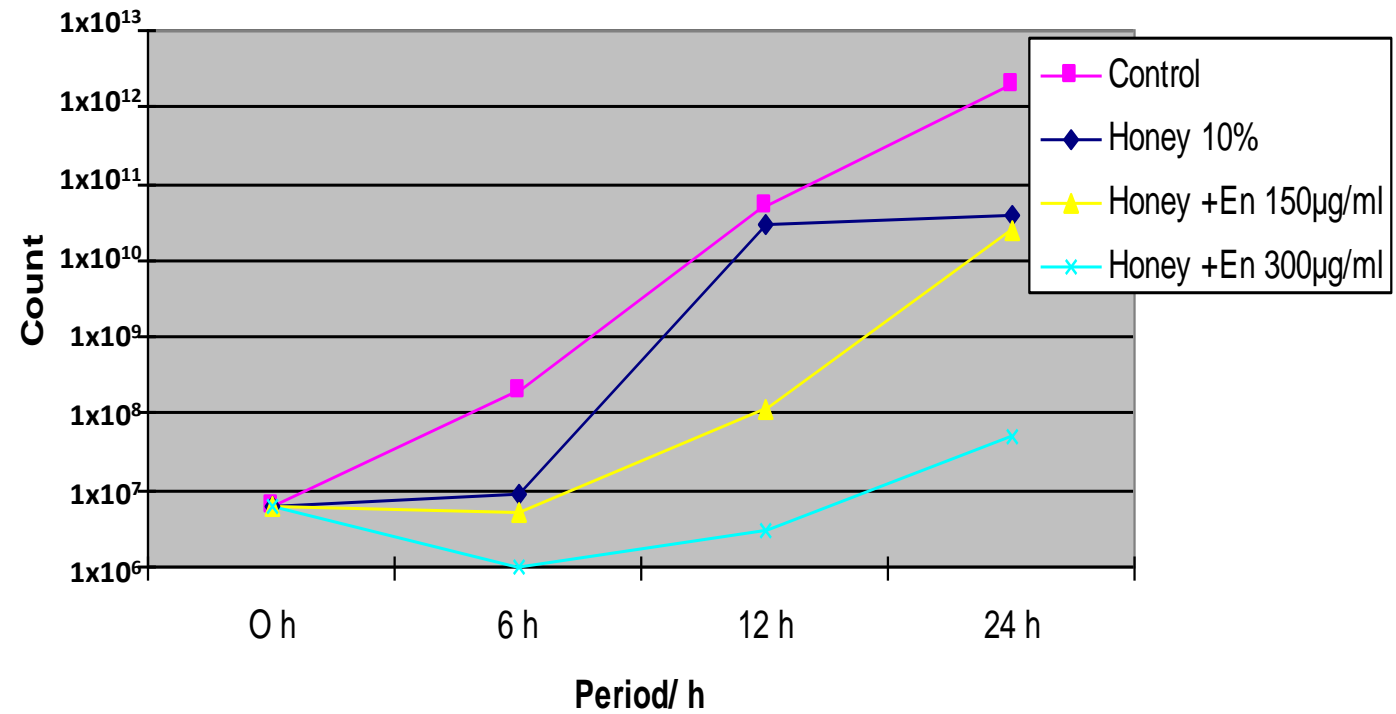

Figure 1: Chart showing E. coli O18 count that grown in UHT milk with $10 \%$ honey and different concentrations of enterocin stored at ambient temperature $\left(30 \pm 2{ }^{\circ} \mathrm{C}\right)$.

Table 2: $\mathrm{pH}$ values of $E$. coli $\mathrm{O} 18$ inoculated in UHT milk with10\%honey and different concentration of enterocin at ambient temperature $\left(30 \pm 2{ }^{\circ} \mathrm{C}\right)$.

\begin{tabular}{lllll}
\hline Period & $\begin{array}{c}\text { UHT milk Control } \\
\text { (additive free) }\end{array}$ & $\begin{array}{c}\text { UHT milk with } \\
\text { honey } 10 \%\end{array}$ & $\begin{array}{l}\text { UHT milk with honey \& } \\
\text { enterocin }(150 \mu \mathrm{g} / \mathrm{ml})\end{array}$ & $\begin{array}{l}\text { UHT milk with honey } \\
\text { enterocin }(300 \mu \mathrm{g} / \mathrm{ml})\end{array}$ \\
\hline $0 \mathrm{~h}$ & 7.16 & 7.07 & 6.54 & 6.26 \\
\hline $6 \mathrm{~h}$ & 7.17 & 6.98 & 6.54 & 6.27 \\
\hline $12 \mathrm{~h}$ & 6.51 & 6.52 & 6.36 & 6.27 \\
\hline $24 \mathrm{~h}$ & 6.21 & 6.08 & 5.93 & 6.13 \\
\hline
\end{tabular}

Table 3: The count and reduction $\%$ of $E$. coli $\mathrm{O} 18$ inoculated in UHT milk with $10 \%$ honey and enterocin at refrigerator temperature $\left(4 \pm 2{ }^{\circ} \mathrm{C}\right)$.

\begin{tabular}{llllllll}
\hline \multirow{2}{*}{ Period } & $\begin{array}{l}\text { UHT milk Control } \\
\text { (additive free) }\end{array}$ & $\begin{array}{l}\text { UHT milk with } \\
\text { honey } 10 \%\end{array}$ & $\begin{array}{l}\text { UHT milk with } \\
\text { honey \& enterocin } \\
(150 \mu \mathrm{g} / \mathrm{ml})\end{array}$ & $\begin{array}{l}\text { UHT milk with honey \& enterocin } \\
(300 \mu \mathrm{g} / \mathrm{ml})\end{array}$ & \\
\cline { 2 - 8 } & $\begin{array}{l}\text { Count } \\
\mathrm{cfu} / \mathrm{ml}\end{array}$ & $\begin{array}{l}\text { Count } \\
\mathrm{cfu} / \mathrm{ml}\end{array}$ & $\begin{array}{l}\text { Red. } \\
\%\end{array}$ & $\begin{array}{l}\text { Count } \\
\mathrm{cfu} / \mathrm{ml}\end{array}$ & $\begin{array}{l}\text { Red. } \\
\%\end{array}$ & $\begin{array}{l}\text { Count } \\
\mathrm{cfu} / \mathrm{ml}\end{array}$ & $\begin{array}{l}\text { Red. } \\
\%\end{array}$ \\
\hline $0 \mathrm{~h}$ & $6.0 \times 10^{6}$ & $6.0 \times 10^{6}$ & - & $6.0 \times 10^{6}$ & - & $6.0 \times 10^{6}$ & - \\
\hline $6 \mathrm{~h}$ & $1.1 \times 10^{8}$ & $1.8 \times 10^{5}$ & 99.84 & $7.0 \times 10^{4}$ & 99.94 & $1.1 \times 10^{5}$ & 99.90 \\
\hline $12 \mathrm{~h}$ & $1.5 \times 10^{7}$ & $4.2 \times 10^{5}$ & 97.20 & $2.6 \times 10^{5}$ & 98.27 & $2.0 \times 10^{4}$ & 99.87 \\
\hline $24 \mathrm{~h}$ & $2.7 \times 10^{7}$ & $2.0 \times 10^{6}$ & 92.59 & $9.9 \times 10^{5}$ & 96.33 & $7.1 \times 10^{4}$ & 99.74 \\
\hline
\end{tabular}




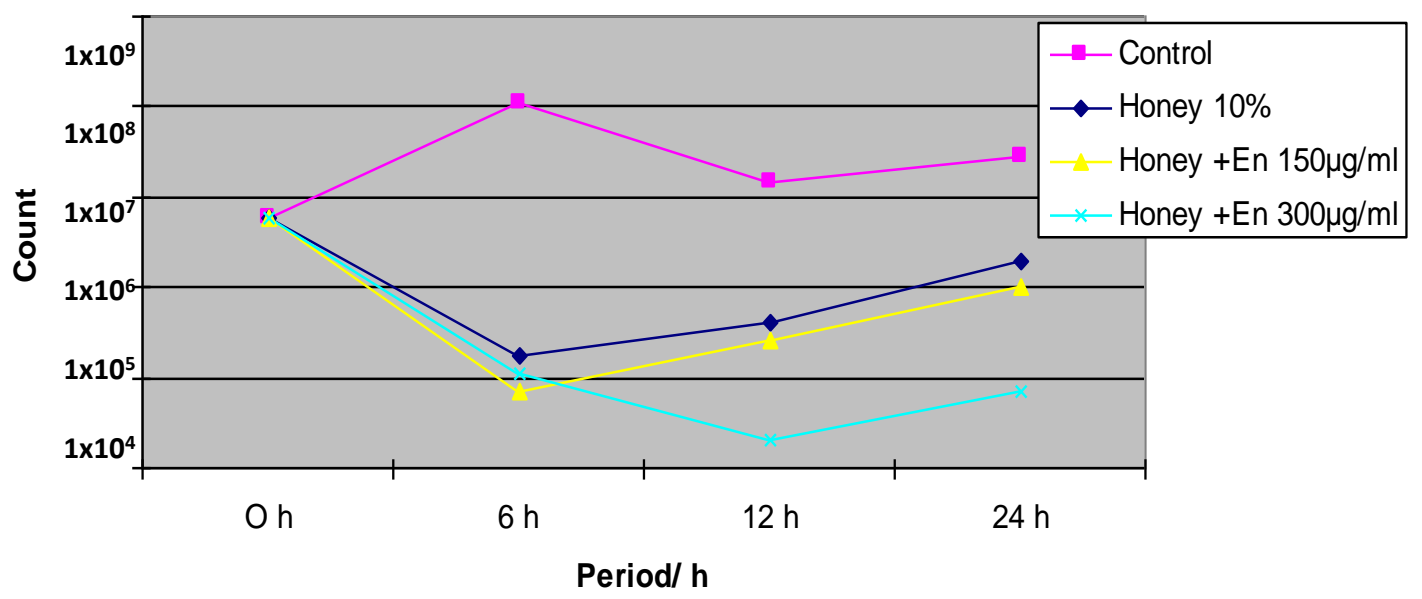

Figure 2: Chart showing E. coli O18 count that grown in UHT milk with $10 \%$ honey and different concentrations of enterocin stored at refrigerator temperature $\left(4 \pm 2{ }^{\circ} \mathrm{C}\right)$.

Table 4: $\mathrm{pH}$ values of $E$. coli $\mathrm{O} 18$ in UHT milk inoculated with $10 \%$ honey and different concentration of enterocin at refrigerator temperature $\left(4 \pm 2{ }^{\circ} \mathrm{C}\right)$.

\begin{tabular}{lllll}
\hline Period & $\begin{array}{l}\text { UHT milk Control } \\
\text { (additive free) }\end{array}$ & $\begin{array}{l}\text { UHT milk with } \\
\text { honey 10\% }\end{array}$ & $\begin{array}{l}\text { UHT milk } \\
\text { honey\& } \\
(150 \mu \mathrm{g} / \mathrm{ml})\end{array}$ & $\begin{array}{l}\text { enterocin } \\
(300 \mu \mathrm{g} / \mathrm{ml})\end{array}$ \\
\hline $0 \mathrm{~h}$ & 7.16 & 7.07 & 6.54 & 6.26 \\
\hline $6 \mathrm{~h}$ & 7.25 & 7.07 & 6.66 & 6.35 \\
\hline $12 \mathrm{~h}$ & 7.17 & 7.01 & 6.62 & 6.31 \\
\hline $24 \mathrm{~h}$ & 7.30 & 7.00 & 6.61 &
\end{tabular}

Table 5: The count and reduction \% of E. coli $\mathrm{O} 18$ inoculated in UHT milk with EDTA (20 mM) and enterocin at ambient temperature $\left(30 \pm 2{ }^{\circ} \mathrm{C}\right)$.

\begin{tabular}{|c|c|c|c|c|c|c|c|}
\hline \multirow{2}{*}{ Period } & \multirow{2}{*}{$\begin{array}{l}\text { UHT milk Control } \\
\text { (additive free) }\end{array}$} & \multicolumn{2}{|c|}{$\begin{array}{l}\text { UHT milk with } \\
\text { EDTA }(20 \mathrm{mM})\end{array}$} & \multicolumn{2}{|c|}{$\begin{array}{l}\text { UHT milk with EDTA \& } \\
\text { enterocin }(150 \mu \mathrm{g} / \mathrm{ml})\end{array}$} & \multicolumn{2}{|c|}{$\begin{array}{l}\text { UHT milk witl } \\
\text { EDTA \& enterociı } \\
(300 \mu \mathrm{g} / \mathrm{ml})\end{array}$} \\
\hline & & $\begin{array}{l}\text { Count } \\
\mathrm{cfu} / \mathrm{ml}\end{array}$ & $\begin{array}{l}\text { Red. } \\
\%\end{array}$ & $\begin{array}{l}\text { Count } \\
\mathrm{cfu} / \mathrm{ml}\end{array}$ & $\begin{array}{l}\text { Red. } \\
\%\end{array}$ & $\begin{array}{l}\text { Count } \\
\mathrm{cfu} / \mathrm{ml}\end{array}$ & $\begin{array}{l}\text { Red. } \\
\%\end{array}$ \\
\hline $0 \mathrm{~h}$ & $1.5 \times 10^{5}$ & $1.5 \times 10^{5}$ & -- & $1.5 \times 10^{5}$ & -- & $1.5 \times 10^{5}$ & -- \\
\hline $6 \mathrm{~h}$ & $9.0 \times 10^{8}$ & $7.3 \times 10^{7}$ & 91.89 & $7.3 \times 10^{6}$ & 99.19 & $1.1 \times 10^{5}$ & 99.99 \\
\hline $12 \mathrm{~h}$ & $1.0 \times 10^{9}$ & $2.0 \times 10^{8}$ & 80.00 & $1.0 \times 10^{6}$ & 99.90 & $2.0 \times 10^{4}$ & 99.99 \\
\hline $24 \mathrm{~h}$ & $1.3 \times 10^{10}$ & $1.2 \times 10^{9}$ & 90.76 & $3.3 \times 10^{6}$ & 99.97 & $7.1 \times 10^{4}$ & 99.99 \\
\hline
\end{tabular}




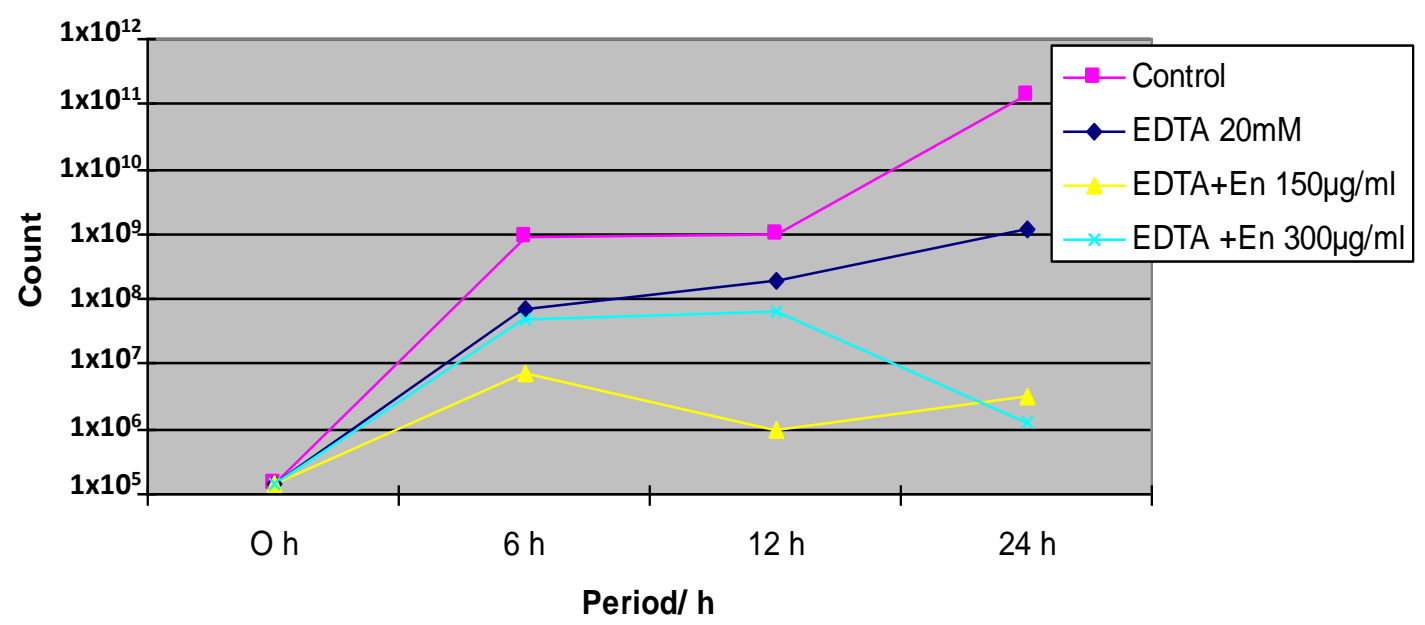

Figure 3: Chart showing E. coli O18 count that grown in UHT milk with EDTA (20mM) and different concentrations of enterocinstored at ambient temperature $\left(30 \pm 2{ }^{\circ} \mathrm{C}\right)$.

Table 6: $\mathrm{pH}$ values of $E$. coli $\mathrm{O} 18$ in UHT milk with EDTA $(20 \mathrm{mM})$ and different concentration of enterocin at ambient temperature $\left(30 \pm 2^{\circ} \mathrm{C}\right)$.

\begin{tabular}{lllll}
\hline Period & $\begin{array}{l}\text { UHT milk Control } \\
\text { (additive free) }\end{array}$ & $\begin{array}{l}\text { UHT milk with } \\
\text { EDTA }(20 \mathrm{mM})\end{array}$ & $\begin{array}{l}\text { UHT milk with } \\
\text { EDTA enterocin } \\
(150 \mu \mathrm{g} / \mathrm{ml})\end{array}$ & $\begin{array}{l}\text { UHT milk } \\
\text { \&enterocin } \\
(300 \mu \mathrm{g} / \mathrm{ml})\end{array}$ \\
\hline $0 \mathrm{~h}$ & 7.22 & 6.24 & 5.94 & 5.73 \\
\hline $6 \mathrm{~h}$ & 7.01 & 6.18 & 5.95 & 5.77 \\
\hline $12 \mathrm{~h}$ & 6.69 & 6.10 & 5.95 & 5.82 \\
\hline $24 \mathrm{~h}$ & 6.26 & 6.04 & 5.93 & 5.82 \\
\hline
\end{tabular}

Table 7: The count and reduction\% of E. coli O18 inoculated in UHT milk with EDTA (20mM) and enterocin at refrigerator temperature $\left(4 \pm 2{ }^{\circ} \mathrm{C}\right)$.

\begin{tabular}{|c|c|c|c|c|c|c|c|}
\hline \multirow{2}{*}{ Period } & \multirow{2}{*}{$\begin{array}{l}\text { UHT milk Control } \\
\text { (additive free) }\end{array}$} & \multicolumn{2}{|c|}{$\begin{array}{l}\text { UHT milk with } \\
\text { EDTA }(20 \mathrm{mM})\end{array}$} & \multicolumn{2}{|c|}{$\begin{array}{l}\text { UHT milk with } \\
\text { EDTA \& enterocin } \\
(150 \mu \mathrm{g} / \mathrm{ml})\end{array}$} & \multicolumn{2}{|c|}{$\begin{array}{l}\text { UHT milk with EDTA } \\
\& \quad \\
(300 \mu \mathrm{g} / \mathrm{ml})\end{array}$} \\
\hline & & $\begin{array}{l}\text { Count } \\
\mathrm{cfu} / \mathrm{ml}\end{array}$ & $\begin{array}{l}\text { Red. } \\
\%\end{array}$ & $\begin{array}{l}\text { Count } \\
\mathrm{cfu} / \mathrm{ml}\end{array}$ & $\begin{array}{l}\text { Red. } \\
\%\end{array}$ & $\begin{array}{l}\text { Count } \\
\mathrm{cfu} / \mathrm{ml}\end{array}$ & $\begin{array}{l}\text { Red. } \\
\%\end{array}$ \\
\hline $0 \mathrm{~h}$ & $1.5 \times 10^{5}$ & $1.5 \times 10^{5}$ & - & $1.5 \times 10^{5}$ & - & $1.5 \times 10^{5}$ & - \\
\hline $6 \mathrm{~h}$ & $3.0 \times 10^{5}$ & $2.0 \times 10^{5}$ & 33.33 & $1.5 \times 10^{5}$ & 50.00 & $1.0 \times 10^{5}$ & 66.67 \\
\hline $12 \mathrm{~h}$ & $1.0 \times 10^{6}$ & $4.0 \times 10^{5}$ & 60.00 & $2.2 \times 10^{5}$ & 78.00 & $1.5 \times 10^{5}$ & 85.00 \\
\hline $24 \mathrm{~h}$ & $2.6 \times 10^{6}$ & $3.8 \times 10^{5}$ & 85.38 & $2.3 \times 10^{5}$ & 91.15 & $3.6 \times 10^{4}$ & 98.62 \\
\hline
\end{tabular}




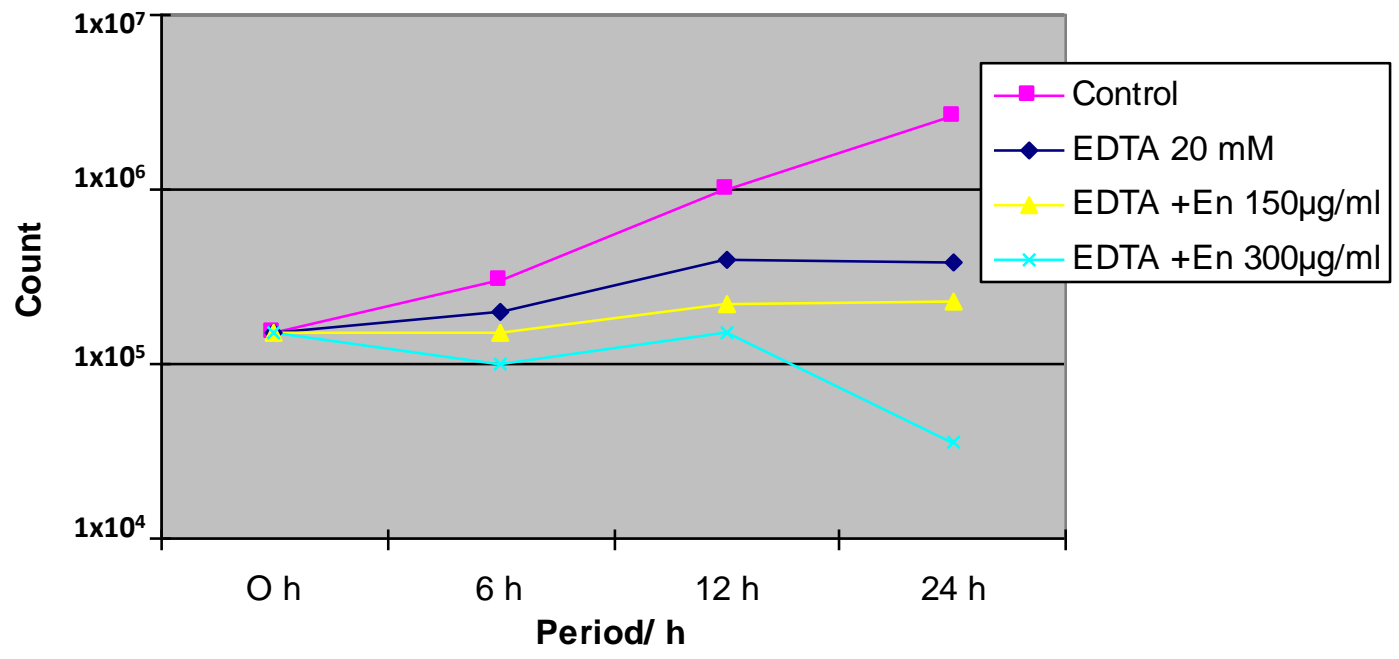

Figure 4: Chart showing E. coli O18 count that grown in UHT milk with EDTA (20mM) and different concentrations of enterocin stored at refrigerator temperature $\left(4 \pm 2{ }^{\circ} \mathrm{C}\right)$.

Table 8: $\mathrm{pH}$ values of $E$. coli $\mathrm{O} 18$ inoculated in UHT milk with EDTA (20mM) and different concentration of enterocin at refrigerator temperature $\left(4 \pm 2{ }^{\circ} \mathrm{C}\right)$.

\begin{tabular}{|c|c|c|c|c|}
\hline Period & $\begin{array}{l}\text { UHT milk Control } \\
\text { (additives free) }\end{array}$ & $\begin{array}{l}\text { UHT milk with } \\
\text { EDTA }(20 \mathrm{mM})\end{array}$ & $\begin{array}{l}\text { UHT milk with } \\
\text { EDTA \& enterocin } \\
(150 \mu \mathrm{g} / \mathrm{ml})\end{array}$ & $\begin{array}{l}\text { UHT milk with EDTA } \\
\text { \&enterocin } \\
(300 \mu \mathrm{g} / \mathrm{ml})\end{array}$ \\
\hline $0 \mathrm{~h}$ & 7.22 & 6.24 & 5.94 & 5.73 \\
\hline $6 \mathrm{~h}$ & 7.23 & 6.29 & 5.95 & 5.78 \\
\hline $12 \mathrm{~h}$ & 7.26 & 6.31 & 6.01 & 5.80 \\
\hline $24 \mathrm{~h}$ & 7.29 & 6.31 & 6.01 & 5.85 \\
\hline
\end{tabular}

\section{DISCUSSION}

Enterococci are found in wide range of environment including milk products and they play an important role in organoleptic characteristics of these products (Giraffa, 2003). They are also known to produce one or more bacteriocin which inhibit the growth of a wide range of foodborne pathogens as E. coli, Salmonella typhimurium, Staph. aureus and Listeria monocytogenes (Kang and Lee, 2005). E. coli is one of the enteropathogenic bacteria which cause gastrointestinal tract disease. E. coli $\mathrm{O} 18$ is one of the enteropathogenic $E$. coli strain, which harbor many virulence factors as intimin (eaeA) and antibiotic resistant genes as bla $a_{T E M}$ and bla CTX-MI (Ewida and Husssein, 2018).

In this study, the inhibitory zone occurred due to the inhibitory effect of enterocin, it was $20 \mathrm{~mm}$ for Staph. aureus which was used as an indicator strain in the antimicrobial activity assay, while, it didn't give any inhibitory zone for the tested E. coli O18. These results agreed with that postulated by Vimont et al. (2017) as they tested the bacteriocin produced by $E$. faecium LCW isolated from camel's milk.

Honey has been used as a medicine in many cultures for long time as in ancient Egypt, the Egyptians considered the honey as the nectar of the gods. Dustmann in 1892 demonstrated the first bactericidal activity of honey (Dustmann, 1989). It is used in the treatment of different pathogenesis caused by bacteria as diarrhea-causing bacteria including E. coli (Adebolu, 2005). Moreover, it is also used in topical treatment of infected wounds and burns (Molan, 2001; Adeleke et al., 2006). The bactericidal action of honey is due to its normal acidity, osmotic effect, high sugar content, enzymes, nitrogenous and other compounds. Also, most types of honey generate hydrogen peroxide, which produced by the activation of glucose to gluconic acid and hydrogen peroxide, which is toxic to bacteria (Jeffrey and Echazarreta, 1996).

The data presented in Table 1\&Fig. 1 showed that the inhibitory effect of the honey $10 \%$ and honey $10 \%$ with different concentrations of enterocin $(150$ 
and $300 \mu \mathrm{g} / \mathrm{ml}$ ) in the UHT milk stored at ambient temperature $\left(30 \pm 2{ }^{\circ} \mathrm{C}\right)$ during $24 \mathrm{~h}$, as the highest reduction of $E$. coli count was obtained by the effect of honey with $300 \mu \mathrm{g} / \mathrm{ml}$ enterocin, where E. coli $\mathrm{O} 18$ count became $5 \times 10^{7} \mathrm{cfu} / \mathrm{ml}$ with percent reduction was $99.99 \%$ at the end of $24 \mathrm{~h}$ of storage. The second reduction count of E.coli $\mathrm{O} 18$ occurred by the addition of honey $10 \%$ with enterocin $150 \mu \mathrm{g} / \mathrm{ml}$, which became $2.5 \times 10^{10}$ $\mathrm{cfu} / \mathrm{ml}$ with inhibitory percent $98.68 \%$. Moreover, the E. coli $\mathrm{O} 18$ count was gradually increased to $3.7 \times 10^{10} \mathrm{cfu} / \mathrm{ml}$ in milk containing honey $10 \%$ alone and the percent reduction was $98.05 \%$. In case of the control UHT milk (additives free), the E. coli O18 count gradually increased until reaching to 1.9 $\mathrm{x} 10^{12} \mathrm{cfu} / \mathrm{ml}$ by the end of $24 \mathrm{~h}$. In addition, the $\mathrm{pH}$ of the UHT milk treated with honey $10 \%$ and enterocin $(150 \mu \mathrm{g} / \mathrm{ml})$ was the lowest $\mathrm{pH}$ value as 5.93 followed by honey $10 \%$ with enterocin $(300 \mu \mathrm{g} / \mathrm{ml})$ as 6.13 , then the UHT treated with honey $10 \%$ only as 6.08 (Table 2 ).

Results in Table 3 \&Fig. 2 depicted the effect of $10 \%$ honey alone and honey $10 \%$ with two different concentrations of enterocin $(150$ and $300 \mu \mathrm{g} / \mathrm{ml})$ in UHT milk containing $E$. coli $\mathrm{O} 18$ stored at refrigerator temperature $\left(4 \pm 2{ }^{\circ} \mathrm{C}\right)$. The initial count of E.coli $\mathrm{O} 18$ was $6 \times 10^{6} \mathrm{cfu} / \mathrm{ml}$ and it decreased to $7.1 \times 10^{4}, 9.9 \times 10^{5}$ and $2 \times 10^{6} \mathrm{cfu} / \mathrm{ml}$ in UHT milk treated with honey with $(300 \mu \mathrm{g} / \mathrm{ml})$ enterocin, honey with $(150 \mu \mathrm{g} / \mathrm{ml})$ enterocin and $10 \%$ honey alone, respectively, after $24 \mathrm{~h}$ storage at refrigerator temperature. Moreover, the inhibitory percents of the previous treatments were 99.74, 96.33 and $92.59 \%$, respectively. However, after $24 \mathrm{~h}$ storage at refrigerator temperature, the count of the tested microorganism in control UHT milk samples (additives free) was increased to reach to $2.7 \times 10^{7}$ $\mathrm{cfu} / \mathrm{ml}$, while, $\mathrm{pH}$ was slightly higher compared to that stored at ambient temperature (Table 4).

EDTA (ethylenediaminetetraacetic acid) is used in the food as antioxidant agent (Silva and Lidon, 2016) and it was added to the list of ingredients that are generally recognized as safe (GRAS) by FDA (Flood, 2016). Also, the current maximum acceptable daily intake (ADI) of EDTA is $1.9 \mathrm{mg}$ day $^{-1} \mathrm{kgbw}^{-1}$ (Wreesmann, 2014).

The outer membrane of Gram-negative bacteria act as a strong barrier to the cell. It prevents the entrance of the antibiotics and detergents to the bacterial cell. Magnesium $(\mathrm{Mg})$ ions are the main ions responsible for stability of the lipopolysaccharide layer of the outer membrane of the bacteria. EDTA is a chelating agent which bind with $\mathrm{Mg}$ ions and removes these ions from the lipopolysaccharide membrane. Thus cause weakening of the outer membrane and the bacteria becomes more susceptible to the antibiotics and detergents (Nikaido and Vaara, 1987).
Regarding the results in Table 5\&Fig. 3, UHT milk samples stored at ambient temperature $\left(30 \pm 2{ }^{\circ} \mathrm{C}\right)$ for 24 hours containing EDTA $(20 \mathrm{mM})$, EDTA $(20 \mathrm{mM})$ with enterocin $(150$ and $300 \mu \mathrm{g} / \mathrm{ml})$, respectively, the counts of $E$. coli $\mathrm{O} 18$ were increased considerably from $1.5 \times 10^{5} \mathrm{cfu} / \mathrm{ml}$ to $1.2 \times 10^{9}, 3.3 \times 10^{6}$ and decreased to $7.1 \times 10^{4} \mathrm{cfu} / \mathrm{ml}$ in UHT milk, in addition, the percent reduction of the previous treatment were 90.76, 99.97 and $99.99 \%$, respectively. While, the count increased in control sample until reaching to $9 \times 10^{8} \mathrm{cfu} / \mathrm{ml}$ by the end of $24 \mathrm{~h}$. The most effective treatment was EDTA with enterocin $(300 \mu \mathrm{g} / \mathrm{ml})$, showing the highest reduction rate of the E. coli $\mathrm{O} 18$ during 24 $\mathrm{h}$ of storing the UHT milk at ambient temperature.

As presented in Table 7 \& Fig. 4, the most effective processing to reduce the number of $E$. coliO18 was addition of EDTA $(20 \mathrm{mM})$ with enterocin $(300 \mu \mathrm{g} / \mathrm{ml})$ and storage the treated UHT milk at refrigerator temperature. The number of $E$. coliat the begging was $1.5 \times 10^{5} \mathrm{cfu} / \mathrm{ml}$, while at the end of 24 hours of storage was $3.6 \times 10^{4} \mathrm{cfu} / \mathrm{ml}$ with inhibitory percent $98.62 \%$. The second effective treatment was EDTA $(20 \mathrm{mM})$ with enterocin $(150 \mu \mathrm{g} / \mathrm{ml})$ followed by EDTA $(20 \mathrm{mM})$ treatment. In contrast, the number of $E$. coli was surge gradually in the control sample (additive free) till reach to $2.6 \times 10^{6} \mathrm{cfu} / \mathrm{ml}$ by the end of $24 \mathrm{~h}$. The lowest $\mathrm{pH}$ was obtained in the treated UHT milk with EDTA and enterocin $(300 \mu \mathrm{g} / \mathrm{ml})$, the $\mathrm{pH}$ value became 5.82 and 5.85 at the end of $24 \mathrm{~h}$ of storage at ambient and refrigerator temperatures, respectively (Tables $6 \& 8$ ).

In conclusion, the addition of honey as natural compound and as EDTA chemical treatment with biopreservative like enterocin had a great inhibitory effect on E. coli O18 growth in UHT milk when stored at refrigerator temperature.

\section{ACKNOWLEDGEMENT}

The authors are indebted to all staff members of Molecular Biology Research Unit, Assiut University, Egypt (Certified ISO/IEC: 17025-2005) for all facilities, great help and encouragement thought this study.

\section{REFERENCES}

A.P.H.A. "American Public Health Association" (2004): Standard Methods for the Examination of Dairy Products, 17th Ed., American Public Health Association, Washington, D.C.

Adebolu, T.T. (2005): Effect of natural honey on local isolates of diarrhea causing bacteria in southwestern Nigeria. African J. Biotechnology, 4: 1172-1174. 
Adeleke, O.E.; Olaitan, J.O. and Okpekpe EI. (2006): Comparative antibacterial activity of honey and gentamycin against Escherichia coli and Pseudomonas aeruginosa. Annals of Burns and Fire Disasters (ISSN 15929566).

Agerholm-Larsen, L.; Bell, M.L.; Grunwald, G.K. and Astrup, A. (2000): The effect of a probiotic milk product on plasma cholesterol: a meta-analysis of short-term intervention studies. European J. Clinical Nutrition, 54: 856-860.

Anderson, E.V. and Gaunt, J.A. (1960): Industrial and Engineering Chemistry, 52, pp.: 190196.

Ananou, S.; Gálvez, A.; Martinez-Bueno, M.; Maqueda, M. and Valdivia, E. (2005): Synergistic effect of enterocin AS-48 in combination withouter membrane permeabilizing treatments against Escherichiacoli O157:H7. J. Appl. Microbiol., 99: 1364-1372.

Boziaris, I.S.; Humpheson, L. and Adams, M.R. (1998): Effect of nisin on heat injury and inactivation of Salmonella enteritidis PT4. Int. J. Food Microbiol., 43: 7-13.

Cutter, C.N. and Siragusa, G.R. (1995a): Population reductions of gram negative pathogens following treatments with nisin and chelators under various conditions. J. Food Prot., 58: 977-983.

Cutter, C.N. and Siragusa, G.R. (1995b): Treatments with nisin and chelators to reduce Salmonella and Escherichia coli on beef. J. Food Prot., 58: 1028-1030.

Djadouni, Fatima (2017): Study of bacteriocin produced by Enterococcus faecium strain isolated from traditional fermented tomatoes in Algeria. Asian J. Biol. Sci., 10: 130-137.

Dustmann, J.H. (1989): Antibacterial effect of honey. Apiacta, 14 (1): 7-11.

Ewida, Rania, M. and Hussein, Asmaa, A.A. (2018): Occurrence of virulent and antibiotic-resistant Enteropathogenic and Shiga toxin- producing Escherichia coli in some milk products sold in Assiut City, Egypt. J. Advanced Vet. Research, 8 (3): 3842.

Flood, A. (2016): 3 Food Ingredients Working Double-Time. https://www.foodinsight.org/ food-ingredients-safe-AzodicarbonamideAzo-Propylene-glycolEthylenediaminetetraacetic-acid-EDTA.

García Garcera', M.J.; Elferink, M.G.L.; Driessen, A.J.M. and W.N. Konings (1993): In vitro pore-forming activity of the lantibiotic nisin. Role of protonmotive force and lipid composition. Eur. J. Biochem., 212:417422.

Giraffa, G. (2003): Functionality of enterococci in dairy products. Int. J. Food Microbiol., 88:
215-222. doi: 10.1016/S0168-1605(03) 00183-1.

Herranz, C. and Driessen, A.J.M. (2005): Secmediated secretion of bacteriocin Enterocin $\mathrm{P}$ by Lactococcus lactis. Appl. Environ. Microbiol., 71: 1959-1963.doi:10.1128/ AEM.71.4.1959-1963.

Jeffrey, A.E. and Echazarreta, C.M. (1996): Medical uses of honey. Rev. Biomed., 7: 43 $-49$

Kalchayanand, N; Sikes, T.; Dunne, C.P. and Ray, $B$. (1994): Hydrostatic pressure and electroporation have increased bactericidal efficiency in combination with bacteriocins. Appl. Environ. Microbiol., 60: 4174-4177.

Kang, J.H. and Lee, M.S. (2005): Characterization of a bacteriocin produced by Enterococcus faecium GM-1 isolated from an infant. J. Appl. Microbiol., 98: 1169-1176.

Kordel, M.; Schüller, F. and Sahl, H.G. (1989): Interaction of the pore forming-peptide antibiotics Pep 5, nisin and subtilin with non-energized liposomes. FEBS Lett., 244:99-102.

Molan, P.C. (2001): Potential of honey in the treatment of wounds and burns. American J. Clin. Dermatol., 2(1): 13-19.

Nikaido, H. and M. Vaara, M. (1987): Outer membrane. In: Escherichia coli and Salmonella typhimurium: cellular and molecular biology, F.C. Neidhardt (Ed.), Vol. 1, pp.: 7-22 American Society for Microbiology, Washington, D.C.

Ohasi, K.; Satonaka, K.; Yamamoto, T.; Yamazaki, M.; Kimura, S.; Abe, S. and Yamaguchi, H. (1992): Antitumor activity of Enterococcus faecalis FK-23 preparation against murine syngeneic tumors. Yakugaku Zasshi, 113: 396-398.

Osmană̆aoğlu, Ö. (2005): Sensitivity of sublethally injured gram negative bacteria to pediocin P. J. Food Safety, 25: 266-275.

Park, S.J.; Kim, J.H.; Lee, K.H.; Yang, J.B.; Baek, Y.J. and Kim, C.H. (1999): Growth inhibition of polysaccharide fraction in cell wall components from Enterococcus faecium 2B4-1 against tumor cell lines. Korean J. Appl. Microbiol. \& Biotechnol., 27: 8-14.

Reuter, G. (1997): Present and future of probiotics in Germany and in central Europe. Bioscience Microflora, 16: 43-51.

Ruhr, E. and Sahl, H.G. (1985): Mode of action of the peptide antibiotic nisin and influence on the membrane potential of whole cells and on cytoplasmic and artificial membrane vesicles. Antimicrob. Agents Chemother., 27: 841-845.

Schillinger, $\quad V$. and Lucke, F.K. (1989): Antimicrobial activity of Lactobacillus sakei 
isolated from meat. Appl. Environ. Microbiol, 39: 189-195.

Schved, F.; Henis, Y. and Juven, B.J. (1994): Response of spheroplasts and chelatorpermeabilized cells of Gram-negative bacteria to the action of the bacteriocins pediocin SJ-1 and nisin. Int. J. Food Microbiol., 21: 305-314.

Schwarzenbach, G. and Heller, J. (1951): Helvetica Chimica Acta, 34: 576- 591.

Silva, M.M. and F.C. Lidon. (2016): Food preservatives - An overview on applications and side effects. Emirates J. Food \&Agric., 28(6): 366-373.

Srinivasan, R.; Karaoz, U.; Volegova, M.; MacKichan, J.; Kato-Maeda, M.; Steve Miller, S.; Nadarajan, R.; Brodie, E. and Lynch, S. (2015): Use of $16 S$ rRNA Gene for Identification of a Broad Range of Clinically Relevant Bacterial Pathogens. https:// doi.org/10.1371/journal.pone.0117617.

Stevens, K.A.; Sheldon, B.W.; Klapes, N.A. and Klaenhammer, T.R. (1991): Nisin treatment for inactivation of Salmonella species and other gram-negative bacteria. Appl. Environ. Microbiol., 57: 3613-3615.

Stiles, M.E. (1996): Biopreservation by lactic acid bacteria. Antonie van Leeuw 70: 331-345.

van Belkum, M.J.; Kok, J.; Venema, G.; Holo, H.; Nes, I.F.; Konings, W.N. and T. Abee. T. (1991): The bacteriocin lactococcin A specifically increases permeability of lactococcal cytoplasmic membranes in a voltage-independent, protein-mediated manner. J. Bacteriol., 173: 7934-7941.

Vimont, A.; Fernandez, B.; Hammami, R.; Ababsa, Ahlem; Hocine Daba, H. and Fliss, I. (2017): Bacteriocin-Producing Enterococcus faecium LCW 44: A High Potential Probiotic Candidate from Raw Camel Milk. Front. Microbiol., 8: 865.

Wreesmann, C. (2014): Reasons for raising the maximum acceptable daily intake of EDTA and the benefits for iron fortification of foods for children 6-24 months of age. Maternal \& Child Nutrition, 10(4): 481-495.

\section{التأثير المثبط للإنتروسين وبعض الإضافات الغذائية على ميكروب الإيشيريشيا كولاي 018 في اللبن المعقم بالحرارة الفائقة رانيا محمد عويضه ، إيناس البرنس محمد}

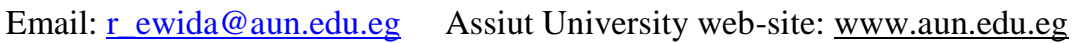

الحفظ الحيوي هي طريقة من أقدم الطرق لحفظ الأغذية وذلك عن طريق إضافة مركبات طبيعية إلى الطعام لزيادة فترة صلاحية

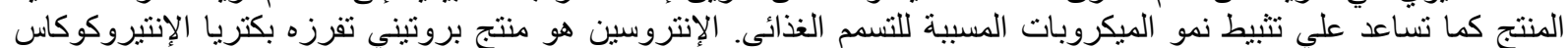

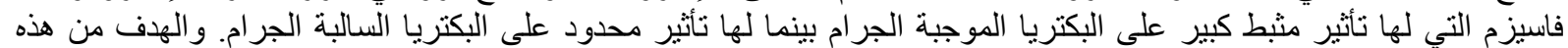

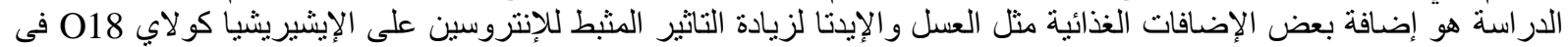

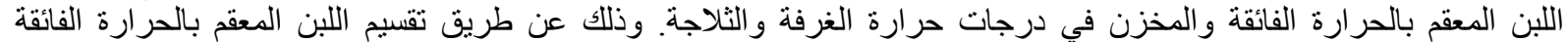

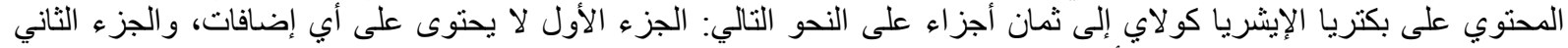

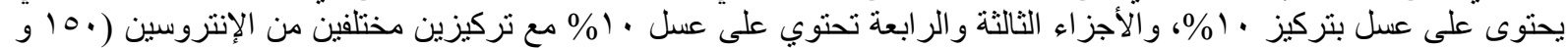

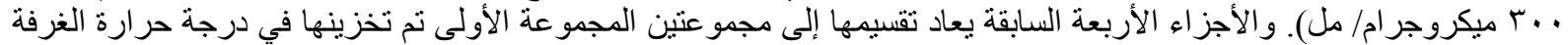

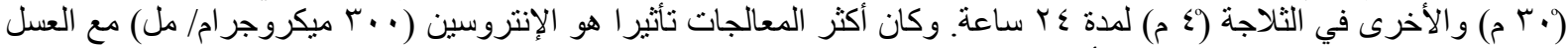

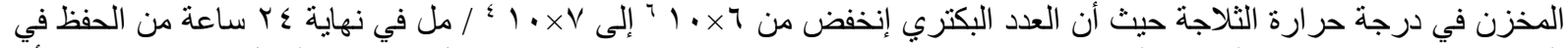

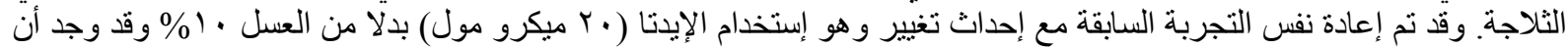

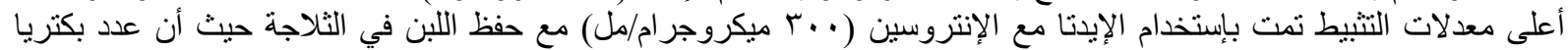

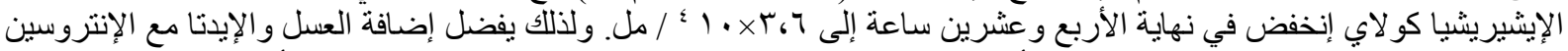

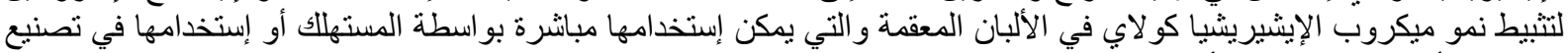
منتجات الألبان مثل الجبن و الأبيس كريم.

الكلمات الكاثفة: الإنتروسين ، العسل، الإيدنا، اللبن المعقم بالحر ارة الفائقة 